Although such role plays may unfold differently from the actual case, participants gain a first-hand experience of being in a network that is underfunctioning. They are able to feed back their reactions and discuss what they might have done differently. We learned, for example, how essential it is for the chairperson to explain why he called the network meeting, and what he hopes to achieve (some definition about his future role); we also saw that he should facilitate the unfolding of the story of the case from all workers present.

The Workshop drew up a comprehensive series of questions which might, in different combinations, help the consultant map the wider system and understand its patterns of relationships (Fig. 2). This information guides him towards offering a new intervention that makes a difference to the case, instead of one which adds to the paralysis.

\section{Consultation to the staff of a unit}

Consultation to a unit usually occurs through a formal request to do so, or arises naturally from a clinical team's involvement with a number of cases referred over time by that unit. This mode of consultation is described well in the literature and the Workshop studied a number of texts. ${ }^{5}$ When a new request for consultation came to the clinical team we used a Workshop to construct a systemic map, and in other Workshops we reviewed participants' current consultation work.

Three members of the Workshop had consulted in turn to the hospital's Child Development Centre, and they offered to present their experiences to the Workshop. In reporting his work each was asked to emphasise how he had entered the Centre (how he had been invited, by whom, for what reason, etc) and how he had left it (the reason for termination, the Centre's response, how it was negotiated, etc).
We learned about our colleagues' successful contributions (e.g. instigating case discussions which helped the Centre co-ordinate their work) and some of their errors (e.g. failing to negotiate the original contract with the head of the Centre, and failing to clarify who was expected to attend the consultation meetings). We also were able to note how transitions in the life of a unit throw group phenomena into sharp relief, when they become available for understanding and resolution. For example, the Centre staff's low self esteem became exaggerated when one consultant left and they returned to a collective belief that people outside the Centre held the solutions to their challenging and difficult work. This false belief had to be made overt and questioned by the retiring consultant in order that his replacement could find a realistic role for himself.

\section{Comments}

Child psychiatrists may be called upon to consult in various ways, and a coherent training in consultation is considered essential for all registrars and senior registrars. Our multidisciplinary Workshop has helped all participants advance their knowledge and skill, and it has enhanced their work as a clinical team.

\section{REFERENCES}

${ }^{1}$ BAteson, G. (1972) Steps to an Ecology of Mind. New York: Ballantine.

${ }^{2}$ Dell, P. (1982) Family theory and the epistemology of Humberto Maturana. In The International Book of Family Therapy (Ed. F. W. Kaslow). New York: Brunner/Mazel.

${ }^{3}$ Selvini Palazzoli, M., Boscolo, L., Cecchin, G. \& Prata, G. (1980) Hypothesizing - circularity-neutrality: three guidelines for the conductor of the session. Family Process, 19, 3-12.

${ }^{4}$ REDER, P. (1986) Multi-agency family systems. Journal of Family Therapy, 8, 139-152.

${ }^{5}$ Selvini Palazzoli, M. (1986) The Hidden Games of Organizations. New York: Pantheon.

\title{
The John Dunn Medal
}

The Irish Journal of Psychological Medicine is offering the first John Dunn Medal for the best contribution accepted for publication in September 1988 or March 1989. The contribution may be an original article or brief report. One of the authors ought to be a trainee in Great Britain or Ireland. The first named trainee will receive the medal.
John Dunn, who was the first Professor of Psychiatry in Ireland and the President of the Royal MedicoPsychological Association, will present the first medal.

Enquiries to: Dr Mark Hartman, Editor, Irish Journal of Psychological Medicine, St Brendan's Hospital, PO Box 418, Rathdown Road, Dublin 7, Ireland. 